This is the accepted version of a chapter that has been published in Professional Networks in Transnational Governance edited by Leonard Seabrooke and Lasse Folke Henriksen published Cambridge University Press, 2017. Published version available from:

https://doi.org/10.1017/9781316855508

Accepted version downloaded from SOAS Research Online: http://eprints.soas.ac.uk/24739/

\title{
ALL THE TRADER'S MEN: \\ PROFESSIONALS IN INTERNATIONAL TRADE POLICYMAKING
}

\author{
Matthew Eagleton-Pierce \\ SOAS University of London \\ Book chapter in:
}

Seabrooke, L. and Henriksen, L. F. (eds), Professional Networks in

Transnational Governance (Cambridge: Cambridge University Press, 2017).

\section{INTRODUCTION}

The creation and legitimation of expert knowledge is the sine qua non of professional work. In the study of transnational governance, across many fields of enquiry, all persons that are commonly called experts seek the power to speak and be heard by relevant audiences. To different degrees, they diagnose, infer, and treat problems of governance that are deemed important (Abbott 1988). Understanding how such knowledge is crafted is a central and enduring analytical challenge. In one major sense, it helps us to explain why and how particular theories and modes of reasoning acquire a legitimised power and who benefits from such privileging. Such analysis also informs our appreciation for how forms of social critique contest and, in certain cases, reshape the orthodoxies of the time. Yet the definition of what makes one type of expertise 'authoritative' and, by contrast, other visions less valid, is a very difficult question to examine, one which necessitates attention to not only canonical bodies of thought, forces of economic materialism, and processes of institutionalisation, but also the working dispositions of the experts themselves. 
This is the accepted version of a chapter that has been published in Professional Networks in Transnational Governance edited by Leonard Seabrooke and Lasse Folke Henriksen published Cambridge University Press, 2017. Published version available from:

https://doi.org/10.1017/9781316855508

Accepted version downloaded from SOAS Research Online: http://eprints.soas.ac.uk/24739/

Within the space constraints here, this chapter aims to unravel part of the nexus between knowledge and power in relation to a particular world of professionals: the policymaking surrounding international trade. Trade experts are scattered across many institutional settings across the world: from government ministries and international institutions, to academic departments and civil society groups. Among the prominent players on this stage are economists who preach the benefits of 'free trade', lawyers who launch into cross-national 'trade wars', and researchers from charities who campaign for 'trade justice'. Some of these experts are full-time members of the trade policy game; they are immersed in its histories, agendas, and customs. Other professionals intervene less frequently or in a selective manner, before addressing other research problems removed from trade politics. Certain professionals work at the coalface of diplomatic policymaking, such as providing counsel to governments on their trade strategies or writing studies that are deemed 'policy-relevant'. Others, by contrast, prefer to operate at a critical distance from such political processes, anxious perhaps of the (negative) connotations or duties that may come from being too close to power.

Drawing upon the conceptual framework of this book, this chapter seeks to ask how one becomes a professional expert on international trade policy and, in particular, what accounts for how certain NGOs have acquired a greater role in such debates. To accomplish this, the argument delineates a new ideal-type categorisation of experts on trade policy: (1) those conventional lawyers and economists, referred to as 'authorized experts'; and (2) a newer class of civil society groups called 'critical technicians'. My major objective is to examine some of the distinguishing qualities of these types of professionals and how they struggle among themselves for social and political recognition. These trade issue professionals exist within a two-level network, coalescing around their own professional networks to mobilise support for issue control, while also engaging with organisations and their strategies for issue control. In this sense, the researchers I aim to objectify may be commonly defined as policy-relevant, although this does not preclude such players engaging in activities that are more autonomous from political forces.

By building upon insights from the sociology of Pierre Bourdieu, the argument probes the different ways in which authorised experts and critical technicians work within the scope of their particular mandates, mobilise resources, and argue for their particular interests. The chapter is organised into three sections. First, a brief conceptual discussion contextualises and unpacks the analytical value of Bourdieu's notions of field and capital. In the second section, through applying these conceptual tools, I explain some of the main attributes of the authorised expert and the critical technician in the world of trade policy. In the final section, to give added detail, I offer a dedicated illustration of a trade politics problem - the West and Central African cotton 
This is the accepted version of a chapter that has been published in Professional Networks in Transnational Governance edited by Leonard Seabrooke and Lasse Folke Henriksen published Cambridge University Press, 2017. Published version available from:

https://doi.org/10.1017/9781316855508

Accepted version downloaded from SOAS Research Online: http://eprints.soas.ac.uk/24739/

issue at the World Trade Organization (WTO) - and explain how particular critical technicians were instrumental in the agenda-setting phase of this initiative.

\section{CONCEPTUAL FRAMEWORK}

As explored by Yves Dezalay and Mikael Rask Madsen in [Chapter x], Bourdieu's conceptual arsenal offers a valuable point of inspiration for the contemporary study of professionals and their working practices. Building upon their discussion, I briefly outline here two notions designed by Bourdieu that can help to enlighten the ways in which professionals emerge, organise, and struggle between themselves for authority: the idea of field and the concept of scientific capital as a form of power. As with any application of Bourdieu's thinking tools, some cautions are required. In one key sense, as I have argued elsewhere in a Bourdieusian-inspired political economy of diplomatic trade talks (Eagleton-Pierce 2013), the proof of the theoretical pudding always remains in its empirical eating. Thus, the deployment of these notions should be read here as an initial sketch and test, one that provides a basis for a richer investigation into the historical ties between expertise and power in the international trading system (Eagleton-Pierce, forthcoming).

Following Weber and Durkheim, Bourdieu characterises modernity as a process of differentiation into relatively independent and increasingly specialised spheres of social action which he calls 'fields' (champ), such as the legal field (Bourdieu 1987), the literary field (Bourdieu 1983, 1993), or the bureaucratic field (Bourdieu 1991, 2004). Four main conceptual properties can be noted. First, Bourdieu characterises fields as spaces of struggle over the control of valued resources. These resources can take many forms, but he underscores how economic power is not the only important object of struggle. Each field thus contains certain central stakes that orientate the activities of agents, notwithstanding their material or normative differences which may be considerable. In contrast to others outside the field, who are not ensconced within its social games, the stakes may appear unimportant or unintelligible. Second, every field has an unequal distribution of power and this has consequences on how opinions are articulated and which speakers acquire legitimacy. This leads one to an examination of what 'chips' - such as particular worldviews, theories, or modes of reasoning are considered meaningful to agents. Third, for Bourdieu, a field tends to impose upon actors specific contests, which they reflect and constitute. Often, agents become 'caught up in the game' and its investments, a sense of illusio as he puts it. They may fail to clearly see how field effects - to be precise, the objective sets of power relations between positions - shape their individual dispositions. Fourth, each field tends to be relatively autonomous in its relations with 
This is the accepted version of a chapter that has been published in Professional Networks in Transnational Governance edited by Leonard Seabrooke and Lasse Folke Henriksen published Cambridge University Press, 2017. Published version available from:

https://doi.org/10.1017/9781316855508

Accepted version downloaded from SOAS Research Online: http://eprints.soas.ac.uk/24739/

other fields, thus enabling agents to identify it. The question of autonomy points to an assessment of field boundaries, including the competition between related fields.

Due to the tendency of professionals to often justify their actions in rational and universal terms, the very suggestion that they marshall and wield 'power' may be met with opposition from such players. But if professionals are concerned with the ability to control knowledge and skill within an area of common work (Abbott, 1988), then Bourdieu's concept of scientific capital can be offered as a vehicle for elucidating the labour involved in such processes. Bourdieu (2004: 55) define this notion as 'a set of properties which are the product of acts of knowledge and recognition performed by agents engaged in the scientific field and therefore endowed with the specific categories of perception that enable them to make the pertinent distinctions, in accordance with the principle of pertinence that is constitutive of the nomos of the field'. ${ }^{1}$ How can this idea be unpacked? By connecting 'science' with 'capital' we are seeking to further politicise the knowledge production process and the agents - both visible and distant - who benefit from it. There are clearly degrees of politicisation in how policy-facing professionals work; the definition of any researcher's 'interest' is, therefore, neither purely 'political' nor purely 'intellectual'. In Bourdieu's view, scientific capital is a type of symbolic recognition which tends to acquire a social profit through two ways: (1) the originality of the knowledge (the degree of innovation in comparison with the norm), and (2) its visibility (exposure and citation of the knowledge by others in the field). Beyond a focus on individual researchers, the control over scientific capital within a designated field is important to assess because each contribution shapes the overall structure of scientific authority, including all the conceptual frameworks, methods, and arguing practices that are regarded as 'orthodox' (the 'correct', 'straight' interpretation) (Bourdieu 1975; 1977).

The extent to which the orthodox forms of scientific capital can change, particularly in response to 'heterodox' critiques, is a key subsequent question. As noted in the introduction, professionals that are established and consecrated often have a proclivity to block rivals from entering their networks who do not share their perspective or who could encroach upon their resources. This often presents considerable challenges to pretenders who want to enter the field and acquire the visibility to redefine the meaning of scientific capital. In other words, if one does not possess the dominant scientific capital, one will probably struggle to be heard because heterodox opinions are not aligned with the principles of legitimacy in the field (Bourdieu 1975). In this chapter, I want to draw attention to this particular problem of how certain heterodox critics

\footnotetext{
1 The idea of scientific capital is derived from Bourdieu's analytical construction of the 'scientific field' in his sociology of science. In my empirical application, the invoking of scientific capital is partly designed to foreground how positivist principles and methods are upheld by many researchers who are engaged in trade policy analysis and, thus, an epistemological affinity can be drawn with the natural sciences.
} 
This is the accepted version of a chapter that has been published in Professional Networks in

Transnational Governance edited by Leonard Seabrooke and Lasse Folke Henriksen published

Cambridge University Press, 2017. Published version available from:

https://doi.org/10.1017/9781316855508

Accepted version downloaded from SOAS Research Online: http://eprints.soas.ac.uk/24739/

maneuver - often in a experimental and tentative manner - towards greater professional recognition for their agendas. It follows that since 'fields exist only through the properties that agents invest in them' (Bigo 2011: 239), the struggle between 'orthodox' and 'heterodox' forms of scientific capital has the potential to modify the structure of the field itself. The practical entry conditions into such professional games, the relative value of the tokens assigned to players, and the strategies adopted in the struggle for control, will now be explored in the particular context of international trade policy.

\section{PROFESSIONAL STRUGGLES OVER TRADE POLICYMAKING}

The analytical construction of trade policy research as a 'field' in the Bourdieusian sense is not without its problems. ${ }^{2}$ In the first instance, as noted, a field must have a core stake that all players gravitate around, providing each agent with an underlying telos or prize to fight over. Despite the range of organisational milieus from which these professionals are drawn from, I would suggest that all trade experts tend to be attracted together by a particular normative inclination: that maintaining a capitalist trading system is a valuable use of political and material resources. It is, in other words, a game that is 'worth the candle'. By way of initial reasoning, many of these professionals are often infused with liberal sensibilities, to different degrees, but especially a universalist and meliorist attitude, as captured in the belief that freer trade is generally beneficial or that trade works as a vehicle for national and 'global' development. Imagining trade policymaking as a field is thus defined through observing how such researchers share certain common dispositions, resulting is 'an objective complicity which underlies all the antagonisms' (Bourdieu 1993: 73). Thus, the professional struggles taking place in this social space are rooted in the power to control the legitimate logic for understanding trade policy and how it may be politically prosecuted. Although this point may appear rather self-evident, particularly to those experts under examination, it realises a greater importance when evaluating the scientific capital considered valuable by these actors in achieving such ends.

A central concern in this volume is to explore how 'issue professionals' can be grasped as an emerging category of actor for governing transnational political life, beyond, but not neglecting, the classic study of professions founded upon a tailored education and formal

\footnotetext{
2 One risk, present even in Bourdieu's scholarship, concerns the potential to have an overproliferation of 'fields', diluting the overall impact of the concept. With my application, it could be suggested that the looser expression of 'social space' may be more preferable rather than field (although both terms are used interchangeably here) or, alternatively, that the arena of trade policy struggles is merely part of a larger 'global' field of power. For some of most careful discussion of such problems, see Didier Bigo, 'Pierre Bourdieu and International Relations: Power of Practices, Practices of Power', International Political Sociology, 5 (2011), 3, 225-258.
} 
This is the accepted version of a chapter that has been published in Professional Networks in Transnational Governance edited by Leonard Seabrooke and Lasse Folke Henriksen published Cambridge University Press, 2017. Published version available from:

https://doi.org/10.1017/9781316855508

Accepted version downloaded from SOAS Research Online: http://eprints.soas.ac.uk/24739/

institutionalisation. As I will argue, this insight informs my argument in two ways. First, compared to the earlier postwar decades, and not ignoring the enduring disciplinary dominance of law and economics, the field of policy-facing international trade research now incorporates a more heterogonous range of experts with different social backgrounds. Second, the argument urges caution with imputing that the organisation to which the professional is attached to or, more generally, their class of organisation (state, NGO, international institution, business etc.), determines their normative interests and working practices. Rather, in keeping with the framework of the book, the discussion here reveals how these knowledge producers exist in a two-level network, forming their own professional networks to mobilise support for their efforts at issue control, while also engaging directly with prominent organisations and their strategies of control.

\section{i. The authorised expert}

Historically, particularly under the shadow of the General Agreement on Tariffs and Trade (GATT), a treaty-based order for organising international trade that ran from 1947 to 1994, the social world of trade experts took on an enclosed appearance. Not unlike other regimes in international relations which call for 'technical' knowledge to understand their political form and stakes, the esoteric, often impenetrably dry subject matter of trade - such as debating the finer points of non-tariff barriers or domestic subsidies - did not enhance the prospect of broader academic or public deliberation. When disagreements arose among these research professionals, it was anticipated that the process for managing disputes would be conducted with discretion, often insulated from not only larger social groups, but other government ministries that were not specifically tasked with a trade remit. In essence, this was a 'selfreferential' community (Weiler 2001: 336). The cultivation of such insularity led, in Robert Howse's (2002: 98) words, to the shaping of a particular 'elite', 'insider network' or 'epistemic community'. Although it would be wrong to depict the agents in this universe as either completely homogenous in their normative outlook or organised according to some calculated and codified plan, there was still a broad liberal ethos and practical 'sense of the game' regarding what problems of international trade merited analytical attention and how they should be treated.

Who are the actors within this field today? In terms of organisational complexes, there are international civil servants, legal interpreters, economists, and statisticians who work within the WTO Secretariat in Geneva. Prominent trade-related departments are also located in other international bodies, including the World Bank, the International Monetary Fund (IMF), the Organisation for Economic Co-operation and Development (OECD), the United Nations Conference on Trade and Development (UNCTAD), and the UN's Food and Agricultural Organization (FAO). More diffusely, through intergovernmental channels, there are current and 
This is the accepted version of a chapter that has been published in Professional Networks in Transnational Governance edited by Leonard Seabrooke and Lasse Folke Henriksen published Cambridge University Press, 2017. Published version available from:

https://doi.org/10.1017/9781316855508

Accepted version downloaded from SOAS Research Online: http://eprints.soas.ac.uk/24739/

former governmental officials who have been given a trade remit and, thus, contribute to public and private dialogues. In the academy, the major trade knowledge producers have a background in economics or law, with international relations and political science as subservient third gateways. Some of these academics may work closely with the policymaking process, such as sitting on WTO dispute settlement panels or consulting for international organisations and governments. However, the majority of academics would still be removed from direct political involvement in this manner. Finally, one can also note private lawyers who advise governments and firms, such as White \& Case and Sidley Austin, the two leading firms with international trade practices, both of which have Geneva offices.

To say that the professionals who work within these circles are 'authorised' is a deliberate label. In one sense, it implies that a process of acquiring authority has been undertaken, culminating in an actor that is held in esteem and appreciation by their peers. In another sense, it invokes the idea that the recognised expert can sanction and countenance other agents or propositions and, thus, reproduce particular processes of authorisation and not others. In economics, for instance, any aspiring authorised expert would be expected to gain mastery over certain foundational principles of trade theory, rooted in the classical insights of Adam Smith but given formal and mathematical expression post-Ricardo (Irwin 1996; Fine and Milonakis 2009; Fourcade 2009). According to professionals who fall within this broad tradition, it is claimed that trade liberalisation exists in a positive relationship with economic growth. Increasing trade provides access to worldwide resources and markets, enlarging the consumption capacities of a country and enabling scale economies. Trade helps to reward those countries that possess a comparative advantage, whether in terms of labour efficiency or other factor endowments. In turn, it is argued that with more growth, a country is in a better position to reduce poverty, as illustrated by the enlarged middle class in China and India. In the contemporary literature, these arguments have built upon a general critique against import-substitution policies which are claimed to foster biases against exporting. Among other undesirable outcomes, it is suggested that such policies can lead to the rationing and misallocation of foreign exchange, the empowering of 'special interests', and the weakening of national institutions (Krueger 1995; Sachs and Warner 1995; Dollar and Kraay 2004; Winters 2004).

A figure such as Jagdish Bhagwati of Columbia University is an emblematic authorised expert who has articulated and echoed such opinions over 60 years. In a foundational sense, he acquired and nurtured a significant volume of scientific capital: an education at Cambridge and MIT; research and academic positions at US, UK and Indian institutions; and a prodigious publications output, including contributions to trade theory, the results of which have been 
This is the accepted version of a chapter that has been published in Professional Networks in Transnational Governance edited by Leonard Seabrooke and Lasse Folke Henriksen published Cambridge University Press, 2017. Published version available from:

https://doi.org/10.1017/9781316855508

Accepted version downloaded from SOAS Research Online: http://eprints.soas.ac.uk/24739/

debated in three separate festchrift volumes. ${ }^{3}$ But his making as an authorised expert on trade, and the manner by which he has moved within a two-level professional network, is more sharply revealed through his public and policy interventions. For instance, Bhagwati has held several high-level consultancy positions within the major trade bodies, including advising the former GATT Director-General Arthur Dunkel, serving on an officially sanctioned expert group that debated the future of the WTO, and acting as an advisor to UNCTAD and other UN agencies. Elsewhere, he frequently writes media commentaries on a range of trade policy questions, including for the Financial Times, the Wall Street Journal, and Foreign Affairs. Although it would be wrong to overstress the influence that Bhagwati has had on some larger trajectories in trade policy - for instance, he has been a trenchant critic of the growth in preferential arrangements beyond the WTO, yet they continue to be negotiated at a significant pace - his consistent work at defending 'globalisation' (Bhagwati, 2004) through distilling neoclassical theory into digestible forms has aided the legitimisation of a certain mainstream perspective.

Beyond Bhagwati, there are many other professionals who could also be called authorised experts on trade. For instance, since the 1960s, John Jackson, Professor of Law at Georgetown University and formally of the University of Michigan, has played a very important role in helping to tutor students in the study of international economic law, leading some commentators to suggest that he 'largely invented the field' (Kennedy 1995: 672). In one sense, Jackson has served as a kind of 'pragmatic conscience for liberal trade without becoming identified with any one issue or policy dispute' (Kennedy 1995: 673). Building upon his insights as a former member of the Office of the US Trade Representative, he has advocated a 'rules-based' international trading order, but conceived as a kind of 'management tool' for businesses and government officials, rather than a utopian narrative (Howse 1999; see Jackson 1997, for a landmark text). One of Jackson's signature policy achievements was helping to build political momentum for the creation of the WTO, first outlined in a Chatham House paper (Jackson 1990), before serving as a consultant for a sympathetic Canadian government who championed the idea and, ultimately, as an advisor to Peter Sutherland, the last GATT Director-General who, in 1994, shepherded the Uruguay Round of trade talks to a close (also see the recounting by VanGrasstek (2013: 50) who notes Jackson's status as the 'father of the WTO').

Nonetheless, most authorised experts are not as visible as Jackson or Bhagwati and, indeed, will never be able (or aspire) to build such volumes of scientific capital in the field. Their everyday forms of professional labour - from deploying computable general equilibrium models

\footnotetext{
${ }^{3}$ Robert C. Feenstra, Gene M. Grossman, and Douglas A. Irwin (eds.), The Political Economy of Trade Policy: Papers in Honor of Jagdish Bhagwati (Cambridge, MA: MIT Press, 1996); V. N. Balasubramanyam and David Greenaway (eds.), Trade and Development: Essays in Honour of Jagdish Bhagwati (Houndsmills: Palgrave, 1996); and Ad Koekkoek and L. B. M. Mennes (eds.), International Trade and Global Development: Essays in Honour of Jagdish Bhagwati (London: Routledge, 1991).
} 
This is the accepted version of a chapter that has been published in Professional Networks in Transnational Governance edited by Leonard Seabrooke and Lasse Folke Henriksen published Cambridge University Press, 2017. Published version available from:

https://doi.org/10.1017/9781316855508

Accepted version downloaded from SOAS Research Online: http://eprints.soas.ac.uk/24739/

that aim to forecast future trade patterns to organising conferences that debate the finer ties between trade and other policy domains - may appear to outsiders as the trappings of a technocracy with its specialised agendas, codes and vocabularies. In the larger galaxy of transnational issue professionals, the authorised experts of trade policy contribute to the seemingly endless process of incrementally remapping the capitalist system around a liberal ethos. But to say that the research practices of all the authorised experts in trade operate within a bounded scientific 'orthodoxy' must always be treated with care since, importantly, the orthodoxy is not some rigidly imposed ideology. On the contrary, part of the efficacy of trade orthodoxy lies in how it adapts to heterodox criticism, even if in a partial or distorted manner (Eagleton-Pierce 2013). In this respect, perhaps the distinguishing quality of an orthodoxy centres on how it reacts to, and fortifies itself against, other potential orthodoxies; opinions that are positioned as heterodox by virtue of having a marginalised status (Berlinerblau 2001). This brings us to consider my argument regarding how the authorised expert has faced competition from other professionals who are more skeptical about the liberal trade project.

\section{ii. The critical technician}

Since the 1990s, the trade policy field has witnessed the emergence of certain critical voices that, I would suggest, have partially disturbed and redefined the logic of what can be considered under the category of trade politics. This is commonly acknowledged by noting the rise of different NGOs, operating at national, regional, and international levels, who have campaigned on trade-related questions. The contemporary seeds of this activism are found in farming collectives and union protests against the GATT Uruguay Round in the 1980s, before morphing into opposition against the North American Free Trade Agreement (NAFTA) and, onwards, to the alter-globalisation movements that coalesced around the turn of the century, including prominent protests at the Seattle WTO Ministerial in 1999 (Murphy 2010; Lang 2011). My interest here is not with those actors whose conduct 'street-level' mobilisations (although I do not discount that the study of these actors remains important) but, rather, in those NGOs that have heavily invested in research on trade policy, a focus that has received only limited attention (Tussie 2009; Hannah 2014). I suggest here that the cultivation of this social critique - where rigorous research is pursued with a contrarian disposition - has forged a new type of professional expert in the world of trade policy, labeled here as the critical technician.

Understanding how the critical technician has entered the trade policy field is a difficult problem to unpack. I would argue that this type of professional began to emerge in the 1990s within a more contestable intellectual environment on trade policy. These field dynamics were partly generated from a small number of prominent empirical economists who were skeptical about the orthodox case for free trade. Thus, work by these authors featured more cautious claims 
This is the accepted version of a chapter that has been published in Professional Networks in Transnational Governance edited by Leonard Seabrooke and Lasse Folke Henriksen published Cambridge University Press, 2017. Published version available from:

https://doi.org/10.1017/9781316855508

Accepted version downloaded from SOAS Research Online: http://eprints.soas.ac.uk/24739/

about what international trade policy could accomplish, especially in terms of the linkages between trade, growth, and poverty. For instance, in one prominent analysis, Francisco Rodríguez and Dani Rodrik (2000: 266) critiqued the econometrics underpinning some major studies, arguing that the relationship between trade 'openness' and growth was not 'general' and 'unambiguous', but most likely 'contingent' and 'dependent on a host of country and external characteristics'. Other more forceful critics, such as Ha-Joon Chang (2002), argued that Western countries only became rich through high tariff walls in earlier phases of their development, contradicting the dominant narrative that border restrictions always lead to regressive outcomes. By the 2000s, such ideas had dovetailed with an examination of how trade policy changes are connected to industrial organisation, domestic institutions, and the socalled 'sequencing of reforms' (Rodrik, 2006). Such thinking was given renewed focus when rules under negotiation at the WTO appeared, from the perspective of some writers, to be narrowing the 'development space' for poorer countries to defend their economic interests (UNCTAD 2002; Wade 2003; Gallagher 2005).

The confluence of these forces - rising popular discontent surrounding the perceived harmful effects of 'globalisation' combined with some important interventions by such economists created more attractive conditions for research-led activism on trade policy. In a Bourdieusian sense, therefore, the boundaries of the field were becoming slightly more porous, facilitating entry points for emerging critical professionals to increase their recognition, but on terms partially of their own making. The work of certain leading figures within Oxfam International can be highlighted as an interesting illustration. In 1991, Kevin Watkins joined Oxfam from the Catholic Institute of International Relations, rising from a Policy Analyst up to the position of Head of Research. One of the major lessons that Watkins took from the 1980s and early 1990s, when the Uruguay Round established the rules for the new WTO, was that activists on trade policy were left significantly behind the main action that shaped the global agenda: corporate lobbying of Western governments (also see Wilkinson, 1996). ${ }^{4}$ Without solid research into monitoring how trade law tended to be framed in favour of the powerful and how, in turn, to propose new agendas that could encourage social and economic justice for all, Watkins argued that Oxfam would not be able to make a major impact. But research alone was insufficient. One also needed strong partnerships with different organisations, including other civil society groups and government ministries (some of which may be ambivalent about Oxfam's role). Finally, the research had to be fused with a third element: the design of tailored campaigning material that would resonate with different targeted audiences, including particular governments, international organisations, the media, and the wider public. ${ }^{5}$

\footnotetext{
${ }^{4}$ Kevin Watkins, former Head of Research, Oxfam International, interview with the author, Oxford, June 13, 2011.

5 lbid.
} 
This is the accepted version of a chapter that has been published in Professional Networks in Transnational Governance edited by Leonard Seabrooke and Lasse Folke Henriksen published Cambridge University Press, 2017. Published version available from:

https://doi.org/10.1017/9781316855508

Accepted version downloaded from SOAS Research Online: http://eprints.soas.ac.uk/24739/

But what forms of scientific capital were considered valuable to professionals such as Watkins as they build a research agenda on trade policy? Oxfam is clearly a diverse confederation of organisations with many competing voices seeking to shape how the resources of the group are deployed. On trade policy, however, Watkins, among others, encouraged a more macro perspective that was not fundamentally 'anti-trade' or 'anti-growth' (stronger attitudes that were common within internal Oxfam debates in the 1980s) but, rather, sought to explain how discriminatory rules of international commerce could be reformed in favour of the poor. ${ }^{6}$ This political choice is important to underline because it returns us to Bourdieu's (1993: 73) point about how a deeper 'complicity' can bind agents together within a field, despite often intense competition between such figures on the surface. If one did not commit to such a starting principle - that the world trade system is a game worth fighting for - Watkins, along with other critical technicians, would not be able to enter the trade policy field and engage with authorised experts. This should not be taken to mean that critical technicians of different colours do not imagine or desire a different capitalist system, or a world beyond capitalism but, rather, that they tend to publically commit to working within the parameters of dominant institutional agendas.

Three major professional tasks confront the critical technician in formulating research that could potentially resonant. First, since the strength of any scientific capital is partly derived from its distinctiveness from the norm, the choice of what trade issue to examine is crucial. In terms of scale, no trade-related NGO or research group, including even larger policy hubs such as the Geneva-based International Centre for Trade and Sustainable Development (ICTSD), have the resources to outcompete the operations of the World Bank, the OECD, or the WTO Secretariat. At the same time, many trade issues, such as those involving rules on origin or anti-dumping codes, have a labyrinthine complexity that is not easily translatable to the many audiences NGOs wish to address. In one sense, therefore, the Oxfam trade 'mandate' is partly structured through which issues can be digested relatively quickly. In particular, if one can find a pertinent and topical 'trigger issue' that illuminates a larger cause - which may be framed under 'social justice' or 'sustainability' - then resources could be better mobilised. ${ }^{7}$ According to Watkins, and reiterated by his predecessor, Duncan Green, this decision is often formed through a range of difficult deliberations over if the issue is 'winnable'; that is, the extent to which a positive policy adjustment could result from the research. These judgments are, however, always tentative, speculative, and founded upon trial-and-error experiences of past research projects. ${ }^{8}$

\footnotetext{
6 Ibid.

7 Ibid.

8 Duncan Green, Head of Research, Oxfam International, interview with the author, London, May 27, 2011.
} 
This is the accepted version of a chapter that has been published in Professional Networks in Transnational Governance edited by Leonard Seabrooke and Lasse Folke Henriksen published Cambridge University Press, 2017. Published version available from:

https://doi.org/10.1017/9781316855508

Accepted version downloaded from SOAS Research Online: http://eprints.soas.ac.uk/24739/

Second, in terms of actual outputs, and further revealing the 'technician' side of their identity, Oxfam reports are often grounded with strong empirics. Explanations may include unpicking the legal inequities within trade rules or using economic modelling and statistical analysis to prove cause-and-effect linkages; that is, deploying similar methodological tools that are legitimately prized by many authorised experts. In addition, the research frequently incorporates punchy quotes from persons 'on the ground' in poor countries - farmers, labourers or other producers - who are claimed to be impacted by the problem under investigation. By combining these sources of evidence, the critical technician is able to appeal to different logics of legitimacy: the rigours of the 'impersonal' scientific method are implicitly respected, yet the numbers are politically interpreted through 'common victims' that are presumed to speak a more 'authentic truth'. Third, a series of other concerns surround what could be called the style or presentation of the critical technician. Here, the appeal to 'killer facts and graphics' (Green 2012) is particularly important as a way to quickly communicate a sense of injustice to the media and political officials. For instance, one of the most memorable 'killer facts' composed by Oxfam was the following: 'Every EU cow receives over $\$ 2$ per day in support and subsidies, more than the income of half the world's people'. According to Duncan Green, composing effective killer facts and graphics can be key to encouraging different audiences to read the associated report. ${ }^{9}$

\section{ILLUSTRATION: THE WTO AFRICAN COTTON INITIAITVE}

In this final section, a particular trade policy issue can be briefly highlighted as a way to explain how Oxfam, as a prominent collective of critical technicians, worked within a two-level network of professional organisation to problematise a neglected trade topic. The case centres on a coalition of West and Central African (WCA) countries - Benin, Burkina Faso, Mali, and Chad - who began campaigning in 2003 at the WTO for the liberalisation of cotton trade. These countries are highly competitive in cotton production and sought greater access to foreign markets, particularly China, in order to enhance their livelihood standards. They argued, however, that their access was being impeded by highly-subsidised US cotton farmers whose own competitiveness was artificially inflated. The issue quickly became a contentious touchstone and absorbed a considerable portion of the WTO's negotiating energy, including spawning a major, related dispute settlement case by Brazil against the US (Eagleton-Pierce 2013).

Oxfam, along with a network of other civil society players, played a significant role in the very creation of 'African cotton' as political issue that needed WTO attention. Although it is often

\footnotetext{
${ }^{9} \mathrm{lbid}$.
} 
This is the accepted version of a chapter that has been published in Professional Networks in Transnational Governance edited by Leonard Seabrooke and Lasse Folke Henriksen published Cambridge University Press, 2017. Published version available from:

https://doi.org/10.1017/9781316855508

Accepted version downloaded from SOAS Research Online: http://eprints.soas.ac.uk/24739/

tricky to identify the relative significance of these contributions and how, in particular, WCA officials interpreted their activism, it is safe to say that the initiative would not have been the same without such input. In the first place, the work of Watkins needs to be credited with mainstreaming the empirical connection between US cotton subsidies and WCA livelihoods. His 2002 report, Cultivating Poverty - backed by strong statistical analysis, a political critique of US cotton policy, and quotes from WCA farmers - had a key impact in terms of increasing information awareness (Oxfam International 2002). As Cultivating Poverty became more widely read and cited, Oxfam's Geneva-based advocacy team plotted how cotton could be articulated in the WTO context. In particular, researchers such as Céline Charveriat and Romain Benicchio consulted with lawyers and analysts based at ICTSD. ${ }^{10}$ The latter group became important in terms of building solidarity between African missions in Geneva, as well as connecting ambassadors with other relevant actors, including a Senegal-based network called Environment and Development Action in the Third World (ENDA or L'organisation internationale enda tiers-monde). ${ }^{11}$ Finally, a consultancy in Geneva called the IDEAS Centre, led by a former Swiss Ambassador, Nicolas Imboden, deserves attention. Imboden's work has been noted by many actors close to the initiative. ${ }^{12}$ One of the differences between the IDEAS Centre and other civil society players was the quality of Imboden's social network: he had the political contacts and acquired expertise to meet regularly with high-level government officials in the region, notably through the Economic Community of West African States (ECOWAS). ${ }^{13}$ Indeed, according to some insiders, Imboden was intimately involved in the drafting of the first official dossier that would be submitted to the WTO (also see Sneyd 2011, Blustein 2009).

If this mobilisation among critical technicians represents one level of professional labour, how did such players interact with the WTO directly? Here, in broad terms, I would suggest that Imboden, along with ICTSD experts, played broker-type roles in order to translate WCA cotton into the WTO negotiating mandate. In order to create a political rupture, but in a manner that would not be easily rejected by defenders of WTO norms and rules, two arguments were advanced. First, despite WCA producers adhering to orthodox trade practices - historically promoted by the US - their efforts were being nullified as a result of discriminatory WTO rules that allowed for excessive subsidisation. Second, Imboden consciously argued that the cotton

10 Romain Benicchio, Advocacy Officer, Oxfam International, interview with the author, Geneva, September 26, 2006.

${ }^{11}$ El Hadji A. Diouf, Programme Coordinator, Africa Trade Programme, International Centre for Trade and Sustainable Development, Geneva, interview with the author, Geneva, September 29, 2006.

12 Imboden's contribution was recognised by WCA policymakers, including Ambassador Samuel Améhou at the Benin mission in Geneva (until 2007); Jason Hafemeister, former Deputy Assistant U.S. Trade Representative for Agriculture and lead negotiator on agriculture during the Doha Round (until 2007); two officials at the WTO Secretariat who declined to be named; and another trade analyst who also wished to remain anonymous.

${ }^{13}$ Nicolas Imboden, Executive Director, IDEAS Centre, interview with the author, Geneva, September 27, 2006. 
This is the accepted version of a chapter that has been published in Professional Networks in Transnational Governance edited by Leonard Seabrooke and Lasse Folke Henriksen published Cambridge University Press, 2017. Published version available from:

https://doi.org/10.1017/9781316855508

Accepted version downloaded from SOAS Research Online: http://eprints.soas.ac.uk/24739/

problem should be read through the frame of 'development', now a highly legitimate term in WTO lexicon due to the latest trade round being labelled a 'development agenda'. By 2004, through a series of arduous political negotiations, this twin approach eventually proved effective at institutionalising WCA cotton as a discrete trade issue in the WTO mandate (Eagleton-Pierce 2013). Thus, to return to a common theme of the book, this example reveals how action among critical technicians was the impetus for an agenda-setting process that would later crystallise into WTO law. At least initially, issue control was not directed by the WTO, other international organisations, or member states, but derived from other policy-facing professionals. In time, however, as cotton became a 'normal' concern, debates became increasingly bureaucratised, including closer involvement of other authorised experts, especially linked to the World Bank (John Baffes) and the WTO Secretariat (Chiedu Osakwe).

\section{CONCLUSION}

This chapter has sought to explore how the professional strategies of policy-relevant experts on trade policy can be better grasped through a Bourdieusian conceptual lens. In their efforts to shape issue control, these professionals navigate within a two-level network: mobilising around their own immediate social milieus and, in certain interventions, engaging with established organisations and their attempts at issue control. As stressed at the beginning, the categories of the authorised expert and the critical technician are ideal-type formulations; further empirical enquiries are needed to substantiate the analytical form and value of such notions. A particular emphasis has been placed on explaining some of the common practices of the critical technician, including the scientific capital that is valued by such figures. On the one hand, many critical technicians target the tensions, inconsistencies, and contradictions within the orthodoxy reproduced by authorised experts. In the words of Luc Boltanski and Eve Chiapello (2007: 495), they are frequently found 'tightening up' the 'tests of justification'; that is, to make whatever is the test of the moment ('liberalisation is good', 'the WTO enables fair negotiations' etc.) 'stricter'. In short, they make the management of power more demanding for the privileged. On the other hand, however, the critical technician always runs a risk that, in pursuit of multiple goals, of which the reproduction of their own networked field position is a key one, they may become overly cautious and stray too close to the more orthodox arguments expressed by the authorised experts. This anxious dance - between a creative ethic that seeks a greater 'good' and the need to appeal to power - lies at the heart of the professional conduct of such players. 
This is the accepted version of a chapter that has been published in Professional Networks in Transnational Governance edited by Leonard Seabrooke and Lasse Folke Henriksen published Cambridge University Press, 2017. Published version available from:

https://doi.org/10.1017/9781316855508

Accepted version downloaded from SOAS Research Online: http://eprints.soas.ac.uk/24739/

\section{REFERENCES}

Abbott, A., The System of Professions: An Essay on the Division of Expert Labor (Chicago: University of Chicago Press, 1988).

Balasubramanyam, V. N. and Greenaway, D., (eds.), Trade and Development: Essays in Honour of Jagdish Bhagwati (Houndsmills: Palgrave, 1996).

Berlinerblau, J., 'Toward a Sociology of Heresy, Orthodoxy, and Doxa', History of Religions, 40 (2001), 4, 327-351.

Bigo, D., 'Pierre Bourdieu and International Relations: Power of Practices, Practices of Power', International Political Sociology, 5 (2011), 3, 225-258.

Blustein, B., Misadventures of the Most Favored Nations: Clashing Egos, Inflated Ambitions, and the Great Shambles of the World Trade System (New York: Public Affairs, 2009).

Boltanski, L., and Chiapello, E., The New Spirit of Capitalism (London: Verso, 2007).

Bourdieu, P., 'The Specificity of the Scientific Field and the Social Conditions of the Progress of Reason', Social Science Information, 14 (1975), 6, 19-47.

Bourdieu, P., Outline of a Theory of Practice (Cambridge: Cambridge University Press, 1977).

Bourdieu, P., 'The Field of Cultural Production, or: The Economic World Reversed', Poetics, 12 (1983), 4-5, 311-356.

Bourdieu, P., 'The Force of Law: Toward a Sociology of the Juridical Field', Hastings Law Journal, 38 (1987), 805-853.

Bourdieu, P. Language and Symbolic Power (Cambridge: Polity Press, 1991).

Bourdieu, P., The Field of Cultural Production: Essays on Art and Literature (Cambridge: Polity Press, 1993).

Bourdieu, P., Sociology in Question (London: Sage, 1993).

Bourdieu, P., Science of Science and Reflexivitiy (Cambridge: Polity Press, 2004).

Bourdieu, P., 'From the King's House to the Reason of State: A Model of the Genesis of the Bureaucratic Field', Constellations, 11 (2004), 1, 16-36.

Chang, H., Kicking Away the Ladder: Development Strategy in Historical Perspective (London: Anthem, 2003).

Dollar, D. and Kraay, A., 'Trade, Growth, and Poverty', The Economic Journal, 114 (2004), 493, F22-F49.

Eagleton-Pierce, M., Symbolic Power in the World Trade Organization (Oxford: Oxford University Press, 2013).

Eagleton-Pierce, M., All the Trader's Men: Expertise and Power in World Trade (forthcoming manuscript).

Fine, B. and Milonakis, D. From Political Economy to Economics: Method, the Social and the Historical in the Evolution of Economic Theory (Abingdon: Routledge, 2009).

Feenstra, R. C., Grossman, G. M., and Irwin, D. A., (eds.), The Political Economy of Trade Policy: Papers in Honor of Jagdish Bhagwati (Cambridge, MA: MIT Press, 1996).

Fourcade, M., Economists and Societies: Discipline and Profession in the United States, Britain, and France, 1890s to 1990s (Princeton: Princeton University Press, 2009).

Gallagher, Kevin, (ed), Putting Development First: The Importance of Policy Space in the WTO and IFls (London: Zed Books, 2005).

Green, D., 'Creating Killer Facts and Graphics', Oxfam Research Guidelines (Oxford: Oxfam GB, 2012).

Hannah, E., 'The Quest for Inclusive and Accountable Governance: Embedded NGOs and Demand Driven Advocacy in the International Trade Regime', Journal of World Trade, 48 (2014), 3.

Howse, R., 'Tribute: The House that Jackson Built: Restructuring the GATT System', Michigan Journal of International Law, 20 (1999), 107-119.

Howse, R., 'From Politics to Technocracy - and Back Again: The Fate of the Multilateral Trading Regime', The American Journal of International Law, 96 (2002), 1, 94-117.

Irwin, D., Against the Tide: An Intellectual History of Free Trade (Princeton: Princeton University Press, 1996).

Jackson, J. H., Restructuring the GATT (London: Chatham House Papers, 1990). 
This is the accepted version of a chapter that has been published in Professional Networks in

Transnational Governance edited by Leonard Seabrooke and Lasse Folke Henriksen published

Cambridge University Press, 2017. Published version available from:

https://doi.org/10.1017/9781316855508

Accepted version downloaded from SOAS Research Online: http://eprints.soas.ac.uk/24739/

Jackson, J. H., The World Trading System: Law and Policy of International Economic Relations (Cambridge, MA: MIT Press, 1997).

Kennedy, D., 'The International Style in Postwar Law and Policy: John Jackson and the Field of International Economic Law', American University International Law Review, 10 (1995), 2, 671-716.

Krueger, A. O., 'Why Trade Liberalisation is Good for Growth', The Economic Journal, 108 (1998), 1513-1522.

Koekkoek, A., and Mennes, L. B. M. (eds.), International Trade and Global Development: Essays in Honour of Jagdish Bhagwati (London: Routledge, 1991).

Lang, A., World Trade Law after Neoliberalism: Re-imagining the Global Economic Order (Oxford: Oxford University Press, 2011).

Murphy, H., The Making of International Trade Policy: NGOs, Agenda-Setting and the WTO (Cheltenham: Edward Elgar, 2010).

Oxfam International, Cultivating Poverty: The Impact of US Cotton Subsidies on Africa, Oxfam Briefing Paper 30 (Oxford: Oxfam International, September 2002).

Rodríguez, F, and Rodrik, D., 'Trade Policy and Economic Growth: A Skeptic's Guide to the Cross-National Evidence', NBER Macroeconomics Annual, 15 (2000), 261-325.

Rodrik, D., 'Goodbye Washington Consensus, Hello Washington Confusion? A Review of the World Bank's Economic Growth in the 1990s: Learning from a Decade of Reform', Journal of Economic Literature, 44 (2006), 4, 973-987.

Sachs, J. D., and Warner, A. M. 'Economic Reform and the Process of Global Integration', Brookings Papers on Economic Activity, (1995), 1, 1-118.

Sneyd, A., Governing Cotton: Globalization and Poverty in Africa (Houndmills: Palgrave Macmillan, 2011).

Tussie, D. (ed), The Politics of Trade: The Role of Research in Trade Policy and Negotiations (Ottawa: International Development Research Centre, 2009).

United Nations Conference on Trade and Development, Trade and Development Report (Geneva: UNCTAD, 2002).

VanGrasstek, C., The History and Future of the World Trade Organization (Geneva: WTO Secretariat, 2013).

Wade, R., 'What Strategies are Viable for Developing Countries Today? The World Trade Organization and the Shrinking of "Development Space"', Review of International Political Economy, 10 (2003), 4, 621-644.

Weiler, J., 'The Rule of Lawyers and the Ethos of Diplomats: Reflection on the Internal and External Legitimacy of Dispute Settlement', in Roger B. Porter, Pierre Sauvé, Arvind Subramanian, and Americo Beviglia Zampetti (eds), Efficiency, Equity, and Legitimacy: The Multilateral Trading System at the Millennium (Washington D.C.: Brookings Institution Press, 2001).

Wilkinson, M. D., 'Lobbying for Fair Trade: Northern NGDOs, the European Community and the GATT Uruguay Round', Third World Quarterly, 17 (1996), 2, 251-267.

Winters, A., 'Trade Liberalisation and Economic Performance: An Overview', The Economic Journal, 114 (2004), 493, F4-F21. 